\title{
VEGETATION CHANGE ON AN URBAN COASTAL DUNE SYSTEM
}

\author{
by Thomas Guy and Jamie B. Kirkpatrick
}

(with one text-figure, six plates and one table)

\begin{abstract}
Guy, T. \& Kirkpatrick, J.B 2018 (14:xii):Vegetation change on an urban coastal dune system. Papers and Proceedings of the Royal Society of Tasmania 152: 1-8. https://doi.org/10.26749/rstpp.152.1 ISSN: 0080-4703. Discipline of Geography and Spatial Sciences, School of Technology, Environments and Design, University of Tasmania, Private Bag 78, GPO Hobart, Tasmania, Australia 7001 (TG, JK*).* Author for correspondence. Email: J.Kirkpatrick@utas.edu.au
\end{abstract}

Coastal environments, not directly transformed by urbanisation but within an urban matrix, can be transformed by changes in climate, invasive species and plantings. We assess changes in vegetation structure since European settlement and changes in native species abundance since 2003 on the cuspate dune complex at Lower Sandy Bay, Tasmania. The pre-European vegetation of the cuspate forehead seems likely to have been grassland dominated by Spinifex sericeus and Austrofestuca littoralis on the foredunes and Eucalyptus viminalis open-forest with a shrubby to grassy understorey on the older dunes. Some trees of E. viminalis still occur on the dune system, together with many elements of the original understorey. The foredune native vegetation had been replaced by Ammophila arenaria closed-grassland by 2003. Much of this grassland was invaded by the native shrub, Acacia longifolia, by 2017. Between 2003 and 2017 almost all native shrub species increased in abundance. Succulent, grass and herb species suffered decline. Increased competition with exotic species, changes in disturbance regimes and decreases in fire frequency in the coastal area are most likely to have influenced the changes in native species distributions.

Key Words: coastal vegetation, dune system, Long Beach Tasmania, native coastal plant species, urbanisation

\section{INTRODUCTION}

Coastal environments are dynamic systems which are constantly responding to changes in climate, weather, landforms, marine conditions and biota, as well as to anthropogenic factors, for example urban development, recreational uses and the introduction of exotic species (Harvey \& Caton 2003, Smith \& Doherty 2006). Dune systems are recognised globally as being important for both biodiversity and human use (Ranwell 1972). Sand dune vegetation is dependent on climatic influences; wind and precipitation are the two most important climatic influences on sand dune vegetation composition (Ashkenazy et al. 2012). The highly disturbed nature of coastal environments leads to a constant state of colonisation (Ranwell 1972). Thus, areas of dry coastal vegetation are vulnerable to invasion by exotic species (Kirkpatrick 1974, O’Shea \& Kirkpatrick 2000, Ivey-Law \& Kirkpatrick 2015).

In the remnant coastal vegetation of Australia, native species richness decreases with urbanisation, whereas, exotic species become proportionally more common (McKinney 2002). Urban development is often accompanied by physical modification to the coastline, increased ground disturbance, invasion of exotic species and general deterioration of the native vegetation (Harris 1991).

Vegetation zonation caused by strong environmental gradients in coastal dune systems allows for the coexistence of diverse vegetation communities in small areas (Biondi 2007) as has been observed in several places on the Tasmanian coast (Bowden \& Kirkpatrick 1974, Chladil \& Kirkpatrick 1989). There is a large pool of native species available for colonisation (Kirkpatrick \& Harris 1995), as well as a large pool of exotics (Gill 2001, O'Shea \& Kirkpatrick 2000). On the coast to the south of the cuspate forehead, there has been a well-documented temporal increase in exotic plant richness, as urbanisation has proceeded (O'Shea \& Kirkpatrick 2000).

Changes in the abundance of particular lifeforms can lead to changes in the species richness of other lifeforms. Increases in abundance or density of trees, shrubs and bushes is referred to as woody encroachment (Ratajczak et al. 2012) or woody thickening (Ivey-Law \& Kirkpatrick 2015). The transition from heathland to scrub is a process in which the tallest species exclude other shade intolerant species under a closed canopy, resulting in an overall reduction in species richness (Bargmann \& Kirkpatrick 2015).

The aim of the present study is to document vegetation change since European settlement to determine whether native coastal plant species have continued to decline on an urbanised coast, as predicted by O'Shea \& Kirkpatrick (2000), and to determine whether lifeform predicts the magnitude of change.

\section{METHODS}

\section{Study area}

The study area is located at Lower Sandy Bay, Hobart, Tasmania. The site extends from Blinky Billy Point (42 $54^{\prime} 50.9^{\prime \prime}$ S, $\left.147^{\circ} 21^{\prime} 39.2^{\prime \prime E}\right)$ to the western end of Nutgrove Beach (4254'31.5"S, $147^{\circ} 20^{\prime} 52.9^{\prime \prime E}$ ) (fig. 1). Rocky coasts adjoin the beach at the southern end of Long Beach, Blinking Billy Point and the southeast end of Nutgrove Beach. Sandy Bay Point is a cuspate forehead, formed by longshore drift from both north and south. Nutgrove and Long beaches have been important areas for recreation by the public since the 1830s. Perceived loss 


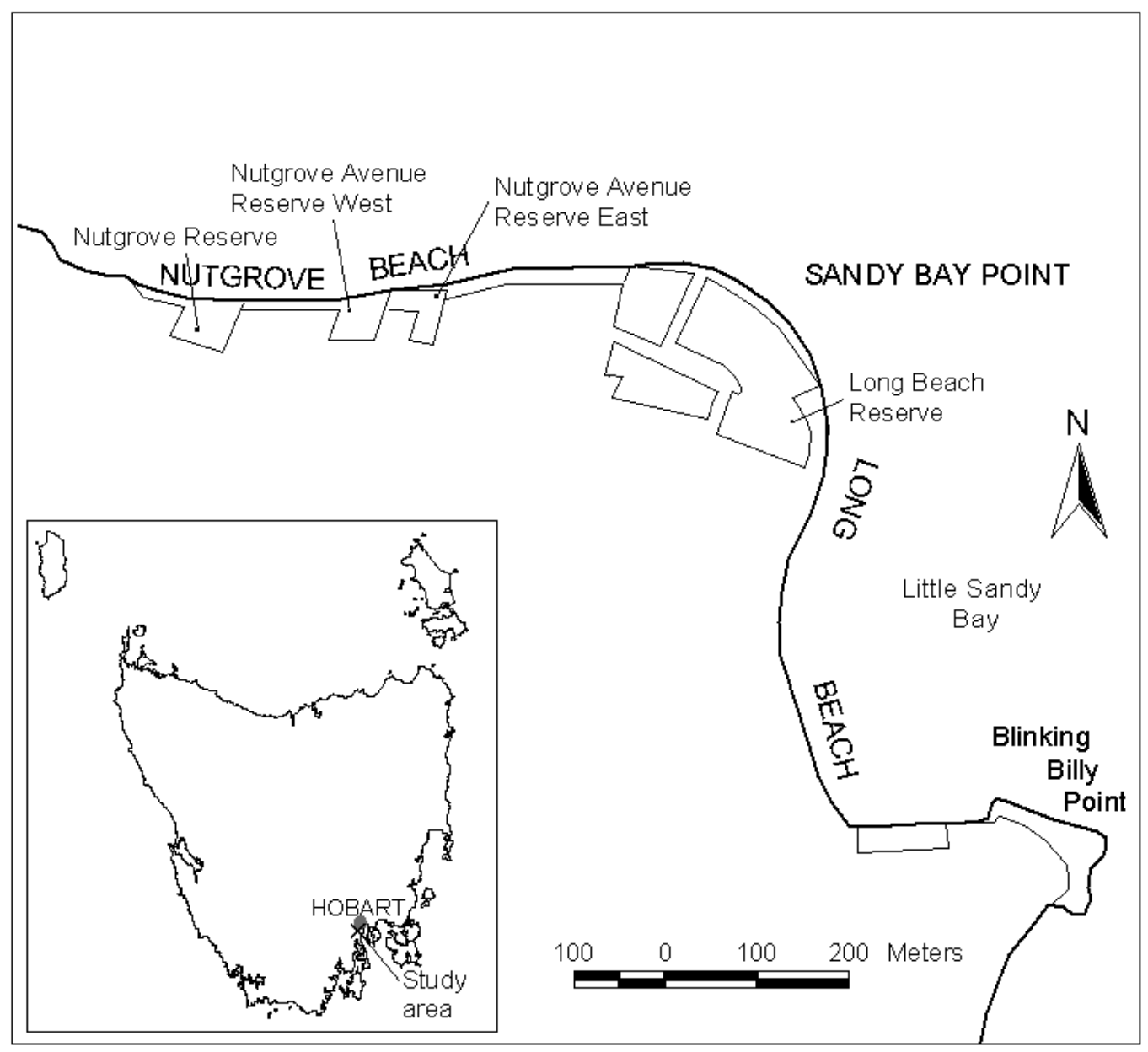

FIG. 1 - Study area.

of sand in the area has been an ongoing issue. Since 1834 the area has undergone natural deposition of sand and supplementary anthropogenic deposition of material in the process of land reclamation (Cruise 1978).

\section{Data collection}

Historical images of the area were obtained from the Tasmanian Library Archive and Heritage Office and the Tasmanian Government's Linc archive website. Photographs were inspected for identifiable plant species and growth forms and compared between successive years. The 2003 data were collected by a University of Tasmania class, under the close supervision of the junior author, who used Global Positioning Devices (GPS) to record the individual locations of every native vascular plant species in the area. The native species in the reserves, and within $15 \mathrm{~m}$ of the coast for those species outside of the reserved areas, were recorded (fig. 1). Twenty-seven native species were recorded. Repeat data collection and mapping was carried out from February to April 2017 and the numbers of individuals compared between the two dates. Areas containing planted native species were excluded from data collection, for example, garden beds. However, individuals that had naturalised from plantings were included.

\section{RESULTS}

Early twentieth century photographs (pls 1, 2, 3) strongly suggest that the stable part of the dune system once supported the same type of coastal forest, dominated by Eucalyptus viminalis, that survives on Rheban Spit, east coast of Tasmania (Bowden \& Kirkpatrick 1974).

There have been substantial changes in the morphology of the study area since 1946 . The most notable change has occurred to the cuspate forehead at the northern end of Long Beach, which has changed in shape. A seawall and concrete walkway have been constructed behind Long Beach. The most obvious change to the vegetation was the replacement of native sand binders (probably Spinifex sericeus and Austrofestuca littoralis) with the introduced marram grass (Ammophila arenaria) on the cuspate forehead of Sandy Bay Point (pls 4, 5, 6). Spinifex sericeus and $A$. littoralis are distinguished from $A$. arenaria in the aerial photographs by their sparse growth form and mounded topography; A. arenaria typically develops $100 \%$ cover and linear dunes (Hayes \& Kirkpatrick 2012) (pl. 4). There appear to be fewer mature trees present in the 2003 and 2017 aerial photographs than in 1946, judging from the degree of canopy closure and the area occupied by forest (pls 4, 5, 6). Tree abundance was similar in 2003 and 2017 , 
PLATE 1 - Long Beach (1939) coastal eucalypt woodland with shrubby understorey as photographed from the southern end of Long Beach Sandy Bay. Some of the trees on the point to the right have survived to the present and are Eucalyptus viminalis. Digitised item from: Tasmanian Library, Tasmanian Archive and Heritage Office https://stors.tas.gov.au/ AUTAS0016125412692.

PLATE 2 - Long Beach (1939) coastal Eucalyptus viminalis woodland with shrubby understorey. Digitised item from: Tasmanian Library, Tasmanian Archive and Heritage Office https://stors.tas.gov.au/ AUTAS0016125412452.

PLATE 3 - Long Beach (pre-1939); coastal Eucalyptus viminalis woodland with shrubby understorey on sand dunes at rear. Digitised item from: Tasmanian Library, Tasmanian Archive and Heritage Office https://stors.tas.gov.au/ AUTAS0016125412452.
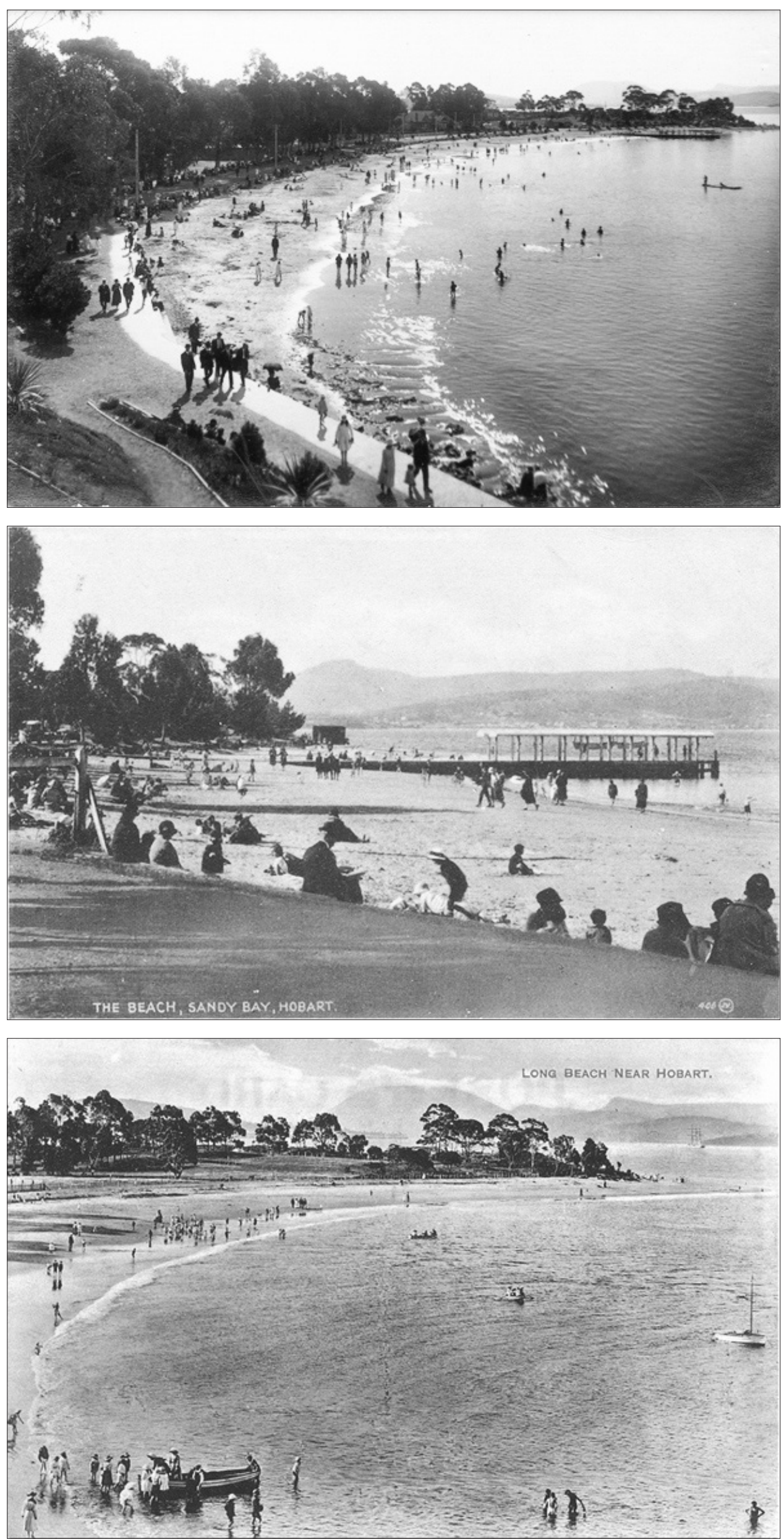

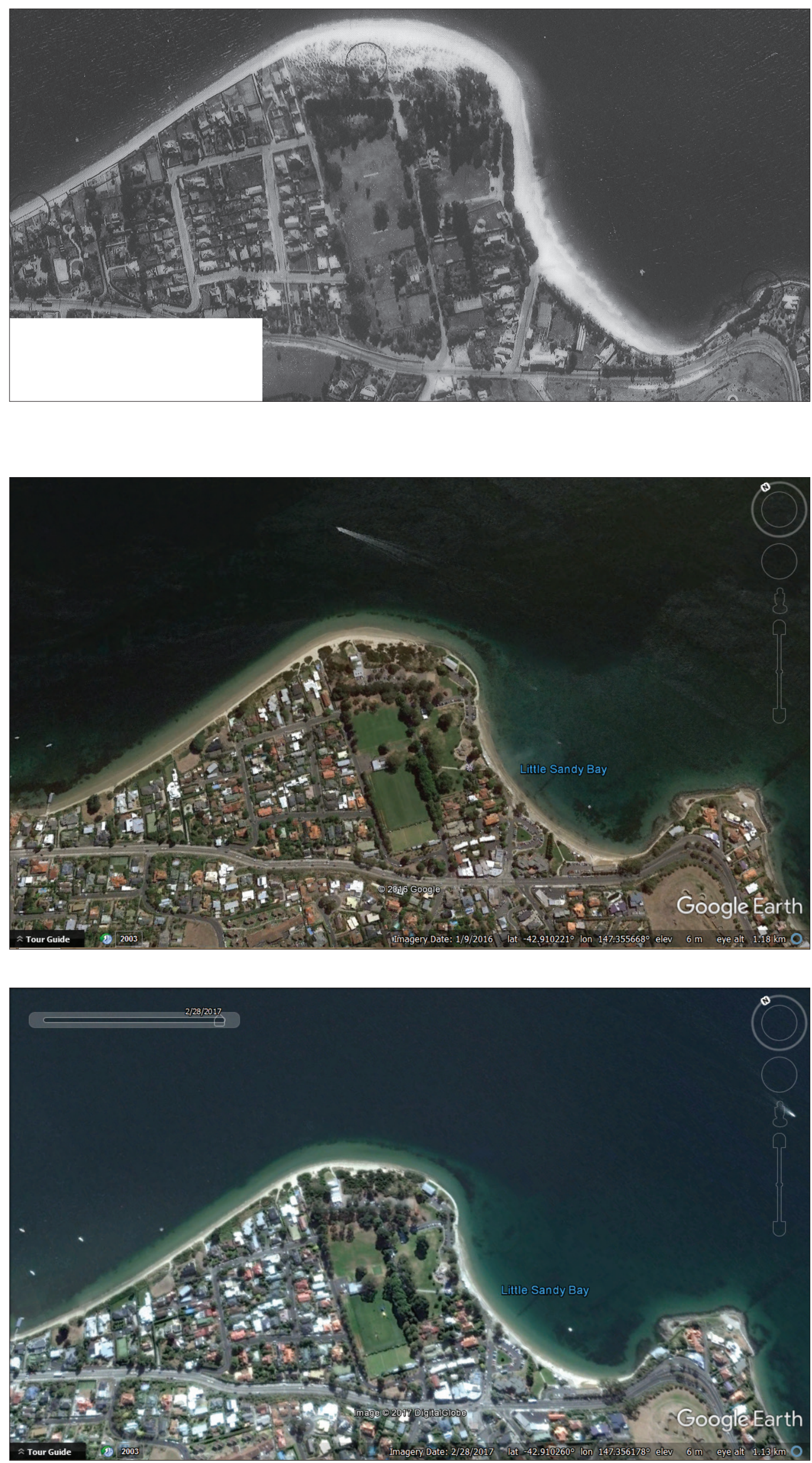

PLATE 4 Composite photograph of study site (1946). The hummocky grassland on the cuspate forehead is typical of native sand-binders. Sourced from Hobart run 81946 11074-11076.

PLATE 5 - Google

Earth image of study site (2003).
PLATE 6 - Google Earth image of study site (2017). 
with 63 and 65 respectively (table 1). Shrubs noticeably thickened between 2003 and 2017 (pls 5, 6).

There were three species (Acacia dealbata, A. melanoxylon and Allocasuarina verticillata) that had the same abundance in 2003 and 2017 (table 1). Ten taxa were observed to have increased in abundance since the 2003 survey: Acacia longifolia subsp. sophorae, Calocephalus brownii, D. brevicaulis, Einadia nutans, Elymus scaber, Eucalyptus viminalis subsp. hentyensis, Pteridium esculentum, Rhagodia candolleana, Sarcocornia quinqueflora and Tetragonia implexicoma (table 1).
There were 12 species observed that had decreased in abundance or were no longer present in the area (table 1): Acaena novae-zelandiae, Austrodanthonia setacea, Austrostipa flavescens, Bursaria spinosa, Carpobrotus rossii, Cynoglossum australe, Dichelachne crinita, Dichondra repens, Eucalyptus globulus, Oxalis perennans, Poa labillardierei and Senecio quadridentatus. Cynoglossum australe is the only species listed as rare or threatened that was located in the study area. There were six individuals recorded in 2003 and only three individuals recorded in 2017.

TABLE 1

Authority, family, lifeform and number of individuals in 2003 and 2017 for native species in the study area.

\begin{tabular}{|c|c|c|c|c|}
\hline Species & Family & Vegetation type & 2003 & 2017 \\
\hline Acacia dealbata Link subsp. dealbata, Enum. & Mimosaceae & Tree & 1 & 1 \\
\hline Acacia melanoxylon R.Br. & Mimosaceae & Tree & 1 & 1 \\
\hline Acacia longifolia (Andrews) Willd. subsp. sophorae (Labill.) Court & Mimosaceae & Shrub & $77^{*}$ & 219 \\
\hline Acaena novae-zelandiae Kirk & Rosaceae & Herb & 1 & 0 \\
\hline Actites megalocarpus (Hook.f.) Lander & Asteraceae & Herb & 0 & 2 \\
\hline Allocasuarina verticillata (Lam.) L.A.S.Johnson & Casuarinaceae & Tree & 0 & 3 \\
\hline Allocasuarina littoralis (Salisb.) L.A.S.Johnson & Casuarinaceae & Tree & 3 & 4 \\
\hline Atriplex cinerea Poir. & Chenopodiaceae & Herb & 6 & 5 \\
\hline Austrodanthonia setacea (R.Br.) H.P.Linder & Poaceae & Grass & $50^{*}$ & 1 \\
\hline Austrostipa flavescens (Labill.) S.W.L.Jacobs \& J.Everett & Poaceae & Grass & 24 & 1 \\
\hline Banksia marginata Cav. & Proteaceae & Shrub & 0 & 1 \\
\hline Bursaria spinosa Cav. subsp. spinosa & Pittosporaceae & Shrub & 12 & 10 \\
\hline Calocephalus brownii (Cass.) F.Muell. & Asteraceae & Herb & 1 & 5 \\
\hline Carpobrotus rossii (Haw.) Schwantes & Aizoaceae & Succulent & 12 & 0 \\
\hline Cynoglossum australe $\mathrm{R} . \mathrm{Br}$. & Boraginaceae & Herb & 6 & 3 \\
\hline Dianella brevicaulis (Ostenf.) G.W.Carr \& P.F.Horsfall & Liliaceae & Herb & 2 & 6 \\
\hline Dichelachne crinita (L.f.) Hook.f. & Poaceae & Grass & 3 & 0 \\
\hline Dichondra repens J.R.Forst. \& G.Forst. & Convolvulaceae & Herb & 2 & 0 \\
\hline Distichlis distichophylla (Labill.) Fassett & Poaceae & Grass & 2 & 0 \\
\hline Dodonaea viscosa Jacq. subsp. spatulata (Sm.) J.G.West & Sapindaceae & Shrub & 0 & 5 \\
\hline Einadia nutans (R.Br.) A.J.Scott & Chenopodiaceae & Herb & 4 & 8 \\
\hline Elymus scaber (R.Br.) Á.Löve & Poaceae & Grass & 2 & 4 \\
\hline Eucalyptus globulus Labill. & Myrtaceae & Tree & $37^{*}$ & 35 \\
\hline Eucalyptus viminalis Labill. subsp. hentyensis Brooker \& Slee & Myrtaceae & Tree & 20 & 22 \\
\hline Isolepis nodosa (Rottb.) R.Br. & Cyperaceae & Sedge & 0 & 4 \\
\hline Myoporum insulare R.Br. & Myoporaceae & Shrub & 0 & 19 \\
\hline Oxalis perennans Haw. & Oxalidaceae & Herb & 4 & 0 \\
\hline Poa labillardierei Steud. var. labillardierei & Poaceae & Grass & 6 & 5 \\
\hline Pteridium esculentum (G.Forst.) Cockayne & Dennstaedtiaceae & Fern & $24^{*}$ & 60 \\
\hline Rhagodia candolleana Moq. & Chenopodiaceae & Shrub & $60^{*}$ & 189 \\
\hline Sarcocornia quinqueflora (Bunge ex Ung. -Sternb.) A.J.Scott & Chenopodiaceae & Herb & 1 & 4 \\
\hline Senecio quadridentatus Labill., Nov. Holl. & Asteraceae & Herb & 13 & 5 \\
\hline Tetragonia implexicoma (Miq.) Hook.f. & Aizoaceae & Herb & 12 & 87 \\
\hline Total & & & 386 & 709 \\
\hline
\end{tabular}

*approximate values as counted from the 2003 maps. 
Five out of six shrub species increased in density between 2003 and 2017 (table 1). Five out of the six grass species have decreased in abundance since 2003. The succulent species (Carpobrotus rossii) was recorded during the 2003 survey but was not found during the subsequent survey in 2017. Pteridium esculentum was the only species of fern observed. It has increased in density in the area. Three of the species (Einadia nutans, Rhagodia candolleana and Tetragonia implexicoma) that have increased in abundance produce a fleshy-fruit (table 1). These three species also have the ability to use other vegetation for support.

\section{DISCUSSION}

Shrub species have increased in density in many different environments since the 1940s (Ivey-Law \& Kirkpatrick 2015, Mitchard et al. 2009, Ratajczak et al. 2012, Bargmann \& Kirkpatrick 2015). Woody thickening causes shrub species to outcompete smaller plant species, such as herbs. This is evident in Sandy Bay in the results from the changes in abundance of small herbs surveyed in 2003 and 2017. Ivey-Law \& Kirkpatrick (2015) made similar observations at the decadal scale in an urban coastal reserve in Melbourne, Australia.

Acacia longifolia has increased in abundance in the area since 2003 (table 1 ). The increase of $A$. longifolia is thought to be due to natural expansion from remnants, as no information could be obtained about planting of this species in the area. Acacia longifolia is a fire-sensitive short-lived species that relies on disturbance to regenerate (Hazard \& Parsons 1977). Although A. longifolia depends on bare ground for regeneration, the expansion of the species has been attributed to decreasing disturbance by both fire and grazing in coastal grasslands environments of New South Wales (Costello et al. 2000). Acacia longifolia can rapidly form closed stands that suppress the growth of shorter species, thereby reducing biodiversity regimes (Clay \& Schneider 2000, Costello et al. 2000). We suggest that $A$. longifolia should be prevented from achieving total dominance, especially in places that support rarer species, such as $C$. australe. Management of $A$. longifolia should be conducted without the use of fire, as the area is highly developed and in close proximity to residential areas. Also, fire stimulates the regeneration of $A$. longifolia (Costello $e t$ al. 2000). Mechanical removal of occasional single plants of A. longifolia may be a more suitable management strategy for this area.

The expansion of shrub species has been related to decreases in the frequency of fire (Roques et al. 2001, Sankaran et al. 2005, Watson et al. 2009). The suburbanisation of the Hobart coast has had a direct impact on fire regimes. The decrease in fire frequency has allowed the invasion of fire-sensitive exotics into nearby coastal cliff vegetation (O'Shea \& Kirkpatrick 2000). Watson et al. (2009) observed that exotic species were most common in areas with infrequent fire events in coastal woodland in New South Wales.
Species that have seed dispersed by birds are increasing in abundance. Birds and ants disperse Acacia longifolia seeds (O’Dowd \& Gill 1986). Tetragonia implexicoma, Einadia nutans and Rhagodia candolleana all possess fruit consumed by birds (Groves 2008, Lepschi 1993, Lindsay \& Meathrel 2008). Tetragonia implexicoma, E. nutans and R. candolleana can smother other vegetation (Harris \& McKenny 1999). Both their dispersal mechanisms and the ability to smother other plants provide a competitive advantage.

Both introduced and native species have the potential to become weedy under the right conditions. It is important to address management at the earliest opportunity rather than once the vegetation becomes established (Hobbs \& Humphries 1995). A number of exotic species were observed during the vegetation sampling. The exotic species which pose the greatest threat to the natives are discussed in greater detail in the following paragraphs.

Marram grass (Ammophila arenaria) has established extensively throughout the study area. Ammophila arenaria has become very common in coastal regions of Australia since it was introduced to stabilise mobile dunes (Hilton $e t$ al. 2006). Ammophila arenaria is highly invasive and as a threat to the ecology of dune systems (Hilton et al. 2005, Wiedemann \& Pickart 2004). The early aerial photographs (pl. 1) indicate native sand-binders where $A$. arenaria is now ubiquitous. The exclusion of the native sand-binder by $A$. arenaria drives changes in shape and structure of dune systems (Hilton et al. 2006, Hayes \& Kirkpatrick 2012). The replacement of native sand-binding species by more competitive exotic sand-binding species facilitates the expansion of shrub species in Tasmanian coastal sand dune systems (Hayes \& Kirkpatrick 2012).

Although the exotic tree, Pinus radiata, may outcompete other species, an understorey of predominantly native species under $P$. radiata occurs in some situations, such as plantations invaded by rainforest species (Brockerhoff et al. 2003) or in the zone of suppression of weed growth by root competition under isolated roadside trees (Kirkpatrick \& Gilfedder 1998). Maintaining P. radiata in the area may provide habitat for some small herbs that would otherwise be excluded by competition from more vigorous plants.

At Rheban spit on the east coast, which shares a similar geomorphology and climate to Lower Sandy Bay, the dominant tree species is E. viminalis on the dunes (Bowden \& Kirkpatrick 1974). The coastal woodland shown in the aerial and historic photographs is dominated by $E$. viminalis, as is indicated by the presence of trees of this species that are still extant.

Although all the species sampled in this study are native to the local area, there are areas of planted native vegetation. In a study of a similar area, Ivey-Law \& Kirkpatrick (2015) refer to this process as ecological gardening. Ecological gardening may not have the ability to return the vegetation to a pre-European state, but it may be useful in order to maintain locally uncommon species (Ivey-Law \& Kirkpatrick 2015).

Remnant vegetation in urban areas is often important for maintaining biodiversity as well as for human recreation (O'Shea \& Kirkpatrick 2000). We suggest that Cynoglossum 
australe be propagated from seed from the surviving plants and planted. The native garden beds in the Hobart City Council reserves would be suitable for planting the species.

As each individual native plant was counted, it is important to note that there is the potential for some individuals to be missed. Given the small size of the study area, the authors are confident that the results have a high degree of accuracy.

The current study sampled standing plants only, whereas the total population of many species on the site may comprise both standing plants and soil seed banks. Therefore, inferences about change address change in the standing plant populations, not necessarily the total population.

\section{CONCLUSION}

Urbanisation and coastal development place considerable pressure on native vascular plant species. The sample site (Sandy Bay, Tasmania) in this study has experienced substantial change since the mid-twentieth century; as demonstrated by the comparison of aerial, historic and present-day photographs of the area, together with the species maps produced in 2003 and again in 2017 . The major changes in the vegetation have been the increase in shrub abundance, which has similarities to other coastal systems. The life forms that have suffered the most decline are succulent, grass and herb species. The loss of the native sand-binding species from the foredunes may have contributed to changing the shape and structure of the dune system, which has led to changes in the vegetation community. The lack of fire in the area in recent times may also be a major contributing factor to shrub expansion.

\section{ACKNOWLEDGEMENTS}

Thanks to the Vegetation Management students in 2003 who collected the initial species distribution data. Thanks also to David Green for the help with equipment and Sophie Campbell for assistance with data collection.

\section{REFERENCES}

Ashkenazy, Y., Yizhaq, H. \& Tsoar, H. 2012: Sand dune mobility under climate change in the Kalahari and Australian deserts. Climatic Change 112: 901-923.

Bargmann, T. \& Kirkpatrick, J.B. 2015: Transition from heathland to scrub in south-eastern Tasmania: extent of change since the 1970s, floristic depletion and management implications. Biodiversity and Conservation 24: 213-228.

Biondi, E. 2007: Thoughts on the ecology and syntaxonomy of some vegetation typologies of the Mediterranean coast. Fitosociologia 44: 3-10.

Bowden, A.R. \& Kirkpatrick, J.B. 1974: The vegetation of the Rheban Spit, Tasmania. Papers and Proceedings of the Royal Society of Tasmania 108: 199-210.

Brockerhoff, E.G., Ecroyd, C.E., Leckie, A.C. \& Kimberley, M.O. 2003: Diversity and succession of adventive and indigenous vascular understorey plants in Pinus radiata plantation forests in New Zealand. Forest Ecology and Management 185: 307-326.

Chladil, M.A., \& Kirkpatrick J.B. 1989: A transect study of the sand dune vegetation at Bakers Beach, Tasmania. Papers and Proceedings of the Royal Society of Tasmania 123: 247-256.

Clay, R.E. \& Schneider, K.E, 2000. The ant (Hymenoptera: Formicidae) fauna of coastal heath in south-west Victoria: effects of dominance by Acacia sophorae and management actions to control it. Pacific Conservation Biology 2: 144-151.

Costello, D.A., Lunt, I.D. \& Williams, J.E. 2000: Effects of invasion by the indigenous shrub Acacia sophorae on plant composition of coastal grasslands in south-eastern Australia. Biological Conservation 96: 113-121.

Cruise, J. 1978: Investigation of Long Point and adjacent beaches. July 1978. Hobart City Council, City Engineers Department, Hobart: 43 pp.

Gill, N. 2001: Predicting Exotic Species Invasions on Tasmanian East Coast Beaches. Unpublished BSc(Hons.) thesis, University of Tasmania, Hobart.

Groves, R.H. 2008: Keynote address: Research on bitou bush and boneseed-a work in progress. Plant Protection Quarterly 23: $15-19$.

Harris, S. \& McKenny, H. 1999: Preservation Island, Furneaux Group: Two hundred years of vegetation change. Papers and Proceedings of the Royal Society of Tasmania 133: 85-102.

Harris, S. 1991: Coastal Vegetation. In Kirkpatrick, J.B. (ed.): Tasmanian Native Bush: A Management Handbook. Hobart, The Tasmanian Environment Centre Inc: 128-147.

Harvey, N. \& Caton, B. 2003: Coastal Management in Australia. Oxford University Press, South Melbourne: $45 \mathrm{pp}$.

Hayes, M, \& Kirkpatrick, J. 2012: Influence of Ammophila arenaria on half a century of vegetation change in eastern Tasmanian sand dune systems, Australian Journal of Botany 60: $450-460$.

Hazard, L \& Parsons, R.F. 1977: Size-class analysis of coastal scrub and woodland, Western Port, South Australia. Australian Journal of Ecology 2: 187-198.

Hilton, M., Duncan, M. \& Jul, A. 2005: Processes of Ammophila arenaria (marram grass) invasion and indigenous species displacement, Stewart Island, New Zealand. Journal of Coastal Research 21: 175-185.

Hilton, M., Harvey, N., Hart, A., James, K. \& Arbuckle, C. 2006 The Impact of Exotic Dune Grass Species on Foredune Development in Australia and New Zealand: a case study of Ammophila arenaria and Thinopyrum junceiforme, Australian Geographer 37: 313-33.

Hobbs, R.J. \& Humphries, S.E. 1995: An integrated approach to the ecology and management of plant invasions. Conservation Biology 9: 761-770.

Ivey-Law, M. \& Kirkpatrick, J.B. 2015: Gardening the wild: change in the flora and vegetation of a suburban coastal reserve 1911-2013. Geographical Research 53: 121-133.

Kirkpatrick, J.B. 1974. Plant invasion and extinction in a suburban coastal reserve. Australian Geographical Studies 12: 107-118.

Kirkpatrick, J.B. \& Gilfedder, L. 1998. Conserving weedy natives: two Tasmanian endangered herbs in the Brassicaceae. Australian Journal of Ecology 23: 466-473.

Kirkpatrick, J.B. \& Harris, S. 1995: The conservation of Tasmanian dry coastal vascular plant communities, Parks and Wildlife Service, Hobart: 129 pp.

Lepschi, B. 1993: Food of some birds in eastern New South Wales: Additions to Barker \& Vestjens. Emu 93: 195-199.

Lindsay, M. \& Meathrel, C. 2008: Where, when and how? Limitations of the techniques used to examine dietary preference of Pacific Gulls (Larus pacificus) using nonconsumed parts of prey and regurgitated pellets of prey remains. Waterbirds: The International Journal of Waterbird Biology 4: 611-619.

McKinney, M.L. 2002: Urbanization, biodiversity, and conservation: the impacts of urbanization on native species are poorly studied, but educating a highly urbanized human 
population about these impacts can greatly improve species conservation in all ecosystems. Bioscience 52: 883-890.

Mitchard, E.T., Saatchi, S.S., Gerard, F.F., Lewis, S.L. \& Meir, P. 2009: Measuring woody encroachment along a forestsavanna boundary in Central Africa. Earth Interactions 13: $1-29$.

O'Dowd, D.J. \& Gill, A.M. 1986: Seed dispersal syndromes in Australian Acacia. In Murray, D.R. (ed.): Seed dispersal. Sydney, Academic Press: 87-121.

O'Shea, E.M. \& Kirkpatrick, J.B. 2000: The impact of suburbanisation on remnant coastal vegetation in Hobart, Tasmania. Applied Vegetation Science 3: 243-252.

Ranwell, D.S. 1972: Ecology of salt marshes and sand dunes. Chapman and Hall London: 219 pp.

Ratajczak, Z., Nippert, J.B. \& Collins, S.L. 2012: Woody encroachment decreases diversity across North American grasslands and savannas. Ecology 93: 697-703.

Roques, K.G., O'Connor, T.G. \& Watkinson, A.R. 2001: Dynamics of shrub encroachment in an African savanna: relative influences of fire, herbivory, rainfall and density dependence. Journal of Applied Ecology 38: 268-280.

Sankaran, M., Hanan, N.P., Scholes, R.J., Ratnam, J., Augustine, D.J., Cade, B.S., Gignoux, J., Higgins, S.I., Le Roux, X., Ludwig, F. \& Ardo, J. 2005: Determinants of woody cover in African savannas. Nature 438: 846-849.

Smith, T \& Doherty, M. 2006: The suburbanisation of coastal Australia. Australian State of the Environment Report 2006.

Watson P.J., Bradstock, R.A. \& Morris, E.C. 2009: Fire frequency influences composition and structure of the shrub layer in an Australian subcoastal temperate grassy woodland. Austral Ecology 34: 218-32.

Wiedemann, A. \& Pickart, A. 2004: Temperate zone coastal dunes, in Martinez, M. \& Psuty, N. (eds): Coastal dunes: ecology and conservation. Berlin, Springer: 53-65.

(accepted 3 July 2018) 